\title{
REALIZATION OF PRODUCTIVITY POTENTIAL AND COMPETITIVENESS OF WINTER WHEAT VARIETIES IN MIXTURES
}

\author{
Tishchenko V. M., Kolesnik A. V., Batashova M. Ye.
}

\section{INTRODUCTION}

Winter wheat breeding has made recent progress in improving the individual productivity of plants by applying various methods for selecting genotypes in hybrid populations. As a result, the vast majority of modern wheat varieties are pure lines in comparison to the old multi-line varieties ${ }^{1}$. The advantages of one-genotype variety are obvious: high productivity of the plants in favorable environments for the genotype, total resistance of plants to certain pathogens, genetically determined resistance to certain abiotic factors, simultaneous passage of organogenesis phases. Nevertheless, the successful implementation of the genotype into high yield results is possible only under sufficiently favorable growing conditions for its growth and development, which may limit the cultivation area of this variety ${ }^{2}$. Farmers in regions with unsustainable farming conditions often mix two or more different varieties to ensure future crop stability ${ }^{3}$. This practice is being successfully developed and applied in various climatic conditions $s^{4,5}$ around the world. Among the advantages of varietal mixtures, their ability to withstand the spread of diseases due to the combination of varieties with resistance to various races of the pathogen comes to the first place ${ }^{6,7,8,9}$. Also,

${ }^{1}$ Bonjean A.P., Angus W.J. The world wheat book. A history of wheat breeding. Paris : Laroisier Publishing and Andover: Intercept. 2001. 1131 p. DOI 10.1006/anbo.2001.1537

${ }^{2}$ Faraji J. Wheat cultivar blends: A step forward to sustainable agriculture. African Journal of Agricultural Research. 2011. № 6(33). P. 6780-6789.

${ }^{3}$ Cowger C., Weisz R. Winter wheat blends (mixtures) produce a yield advantage in North Carolina. Agronomy Journal. 2008. № 100(1). P. 169-177. DOI 10.2134/agronj2007.0128

${ }^{4}$ Finckh M.R., Gacek E.S., Goyeau H., Lannou C., Merz U., Mundt C.C., Munk L., Nadziak J., Newton A.C., de Vallavieille-Pope C., Wolfe M.S. Cereal cultivar and species mixtures in practice. Agronomie: Plant Genetics and Breeding. 2000. № 20. P. 813-837.

5 Wolfe M.S. Variety mixtures in theory and practice. Scottish Crop Res. Inst., Invergowrie, Dundee, Scotland. 2001. URL: http://www.scri.sari.ac.uk/TiPP/Mix/Booklet/ default.htm (assessed 26 June 2007; verified 23 Oct. 2007).

${ }^{6}$ Cowger C., Mundt C.C. Effects of wheat cultivar mixtures on epidemic progression of Septoria tritici blotch and pathogenicity of Mycosphaerella graminicola. Phytopathology. 2002. № 92, P. 617-623. DOI 10.1094/PHYTO.2002.92.6.617

Mundt C.C. Use of multiline cultivars and cultivar mixtures for disease management. Annu. Rev. Phytopathol. 2002. 40. P. 381-410. 
there is an increase in the competitive ability of mixed varieties to weeds ${ }^{10,11}$. In some studies, a $10-20 \%$ of increase in the yield of mixtures in comparison with their pure varietal counterparts is noted, especially under stressful environmental conditions, while in favorable years there are no significant differences ${ }^{12}$.

Currently, there are three different points of view on the relationship between the competitiveness of a genotype in mixture and its productivity in pure line: 1) the productivity of a variety is negatively related to its competitive ability, therefore, in breeding, preference should be given to slightly competitive varieties tolerant to high density growing ${ }^{13,14,15,16,17}$ in these cases, aggressive genotypes suppress others which are high productive in pure line and effective selection from the mixture in the presence of competition is impossible; 2) some researchers note that there is no connection between the productivity of a genotype in pure line and its competitive ability in a mixture ${ }^{18}$; 3) others note this relationship is positive $^{19}$.

The effects of intraspecific genotype competition between plants in agrocenosis sometimes play a key role, but, unfortunately, are not taken into account in breeding practice, which significantly reduces and sometimes

\footnotetext{
${ }^{8}$ Newton A.C., Hackett C.A., Swanston J.S. Analysing the contribution of component cultivars and cultivar combinations to malting quality, yield and disease in complex mixtures. Journal of the Science of Food and Agriculture. 2008. № 88. P. 2142-2152.

${ }^{9}$ Newton A.C., Guy D.C. The effects of uneven, patchy cultivar mixtures on disease control and yield in winter barley. Field Crops Research. 2009. № 110. P. 225-228.

${ }^{10}$ Andrew I.K.S., Storkey J., Sparkes D.L. A review of the potential for competitive cereal cultivars as a tool in integrated weed management. Weed Res. 2015. 55, № (3). P. 239-248. DOI 10.1111/wre.12137

${ }^{11}$ Andrew I.K.S., Storkey J. Using simulation models to investigate the cumulative effects of sowing rate, sowing date and cultivar choice on weed competition. Crop Protection. 2017. № 95, P. 109-115. DOI 10.1016/j.cropro.2016.05.00

${ }_{12}$ Swanston, J.S. Newton A.C., Brosnan J.M., Broadhead A., Glasgow E. Determining the Spirit Yield of Wheat Varieties and Variety Mixtures. Journal of Cereal Science. 2005. № 42. P. 127-134.

${ }^{13}$ Guzhov Yu.L., Komar O.A. Competitiveness of plants of wheat varieties having different stem lengths when sowing in a mixture and separately. VASKhNIL Reports. 1981. 1, № 6. (rus).

${ }^{4}$ Chekalin N.M., Yakovlev V.L., Varlakhov M.D. Report II. The effect of genotypic and environmental competition on the quantitative traits of peas. Genetics. 1983. 19, № (8). P. 1308-1311 (rus)

Donald C.M. The breeding of crop ideotypes. Euphytica. 1968. № 17(3). P. 385-403.

16 Fasoulas A. Correlation between auto-, allo- and nilcompetition and their implication in plant Breeding. Euphytica. 1990. № 50(1). P. 57-62.

${ }_{7}$ Hamblin J., Rowell J.G. Breeding implication of the relationship between competitive ability and pure culture yield in self-pollinated grain crops. Euphytica. 1975. № 24(1). P. 221-228.

${ }^{18}$ Gedge D.L. et al. Influence of intergenotypic competition on seed yield of geterogeneous soybean lines. Crop Sci. 1978. № 18(2). 233 P.

${ }_{19}$ Nikitenko G.F., Gorkov V.P. Features of the selection of elite plants on continuous ordinary crops. Selection and seed production. 1976. № 2. P. 66-68. (rus)
} 
nullifies the selection efficiency in the early breeding stages ${ }^{20}$. With growing winter wheat plants in a selection nursery with generally accepted density, the variability will be mainly determined by the genotype variance of competitive ability, which suppresses genotype expression ${ }^{21,22}$. With low density plant growing the competition between plants for soil and air nutrition and moisture is reducing or completely eliminating, which is actually practiced in breeding. In this case, one of the reasons of low efficiency of individual selection is ignoring the coenotic component of the productivity of agrophytocenosis, because selection is carried out at organism level, and the final assessment of breeding material in variety testing is carried out on coenotic level ${ }^{23}$. So, it was shown that plants with high potential productivity are not sources of highly productive populations $^{24,25}$.

Thus, in increasing the efficiency of selection, the main problem is the identification of the genotype by phenotype, to solve which it is most important to remove the "noise" of environmental and genotypic competition. "Noise" usually means the variability that prevents extrapolating the productivity of an individual plant in population to the productivity of a unit area of cenosis ${ }^{26,27,28}$.

\section{Productivity of wheat plants under intraspecific genotypic competition}

The objective of this study was to investigate the possibility of realization of productivity by wheat plants in conditions of intraspecific

${ }^{20}$ Chekalin N.M., Yakovlev V.L., Varlakhov, M.D. Genotypic and environmental competition in peas (Pisum sativum L.). Report I. The effect of genotypic competition on seed productivity in peas. Genetics. 1983. № 19(8). P. 1301-1307. (rus)

${ }_{2}$ Dragavtsev V.A. New principles for the selection of genotypes by quantitative traits in plant breeding. Genetics of quantitative traits of agricultural plants, Moscow : Science. 1978. P. 5-9. (rus)

${ }_{22}$ Dyakov A.B., Dragavtsev V.A. Competitiveness of plants according to the breeding. Report 1 . Reliability of the assessment of genotypes by phenotypes and the way to increase it. Genetics. 1975. № 11(5). P. 11-22. (rus)

${ }^{23}$ Dolotovsky I.M Genetic and breeding aspects of the mutual influence of plants. Ufa : BFAN USSR. 1987. 102 p. (rus)

${ }^{24}$ Smalko A.A. Mathematical analysis of the relationship between the productivity of plants and their populations. Genetics of quantitative traits of agricultural plants, Moscow : Science. 1978. P. 34-47. (rus)

${ }^{25}$ Chekalin N.M., Belyaeva E.G. Variability of characters in winter wheat populations depending on the type and direction of selection. Breeding and Seed Production. 1986. № 2. P. 15-16. (rus)

${ }^{26}$ Dragavtsev V.A., Shkel N.M. Problems of increasing the efficiency of selection in plants. Biol. fundamentals of breeding for productivity, Tallinn. 1981. P. 102-105. (rus)

${ }^{27}$ Konovalov Yu.B., Al-Sobakhi S.S. Forecast of the effectiveness of selection from crops of various densities in varieties of spring soft wheat. TSHA Reports. 1983. № 5. P. 43-50. (rus)

${ }_{28}$ Maltsev A.V., Dragavtsev V.A., Burdun A.M. Effects of plant interactions in phytocenoses. St. Petersburg. 1991. 44 p. (rus) 
genotypic competition. In this study, we assessed the competitiveness of four varieties of winter wheat on the basis of our own experiments and theoretical developments, we set the following goals: to describe the competitiveness of the varieties of winter wheat and the relationship of competitiveness with yield and some agronomic parameters and indices used in breeding; c) to search for simple traits and more complex indices that could play the role of markers of plant productivity for the selection both in the presence and absence of competition; d) to study the possibility of using component mixtures of low-competitive varieties with different levels of quality in the technology of growing winter wheat in order to increase productivity.

The experiment was carried out at the research field of Plant Breeding Centre of Poltava State Agrarian Academy in Poltava region of Ukraine in 2017-2018. This region is situated in Forest-Steppe climatic zone of Ukraine with $562 \mathrm{~mm}$ of annual rainfall, characterized by continental climate with frost winters, spring delays and summer droughts and in whole by very unstable environmental conditions.

As a material for research, four winter wheat varieties were taken: Levada, Redut, Dolya and Venera. The seeds of each variety were sown: (i) in mixtures according to the diallelic scheme; (ii) in mixture of four varieties in equal quantities and (iii) in pure variety. The plot size was 16.5 $\mathrm{m}^{2}$, four replications.

Before harvesting, 50 plants of each variety from mixture plots and 50 plants from pure varieties plots were randomly selected for measuring agronomic parameters: productive tillering $(\mathrm{PT})$, plant height $(\mathrm{H})$, grain weight per ear $(\mathrm{GW})$, dry stem weight (SW). The some indices were used for plant productivity study: linear ear density (LED) = number of grains per ear / ear length, Poltavskii index $(\mathrm{PI})=$ grain weight per ear / last internode length ${ }^{29}$.

The competitiveness of winter wheat varieties was determined, on the one hand, as the change of trait value of variety in mixture in comparison with trait value of pure variety $(\Delta \mathrm{Xi})$, and on the other hand, as the change of trait value in mixture of varieties in comparison with the value of this trait in pure varieties $(\Delta \mathrm{Xj})$. In this experiment, trait values were calculated as follows for each variety:

$$
\begin{gathered}
\Delta \mathrm{XiL}=(\mathrm{XL}(\mathrm{D})+\mathrm{XL}(\mathrm{R})+\mathrm{XL}(\mathrm{V})) / 3 \mathrm{XL}(\mathrm{L}) \cdot 100-100 \\
\Delta \mathrm{Xj}=(\mathrm{XD}(\mathrm{L})+\mathrm{XR}(\mathrm{L})+\mathrm{XV}(\mathrm{L})) /(\mathrm{XD}(\mathrm{D})+\mathrm{XR}(\mathrm{R})+\mathrm{XV}(\mathrm{V})) \cdot 100-100
\end{gathered}
$$

where, $\Delta \mathrm{XiL}$ is the deviation of trait of variety $\mathrm{L}$ in mixture from pure line; XL (D) ... XL (V) - variety L in mixtures with other varieties; XL (L) pure variety $\mathrm{L} ; \triangle \mathrm{XjL}$ - deviation of varieties in mixtures with variety $\mathrm{L}$ from

${ }^{29}$ Tishchenko V.N., Chekalin N.M. Genetic principles of adaptive breeding of winter wheat in the forest-steppe zone. Poltava. 2005. 270 p. (rus) 
pure lines; XD (L) ... XV (L) - varieties in mixtures with variety L; $\mathrm{XD}(\mathrm{D}) \ldots \mathrm{XV}(\mathrm{V})$ - pure varieties.

Coefficient of competitiveness (CC) of varieties in four-component mixture was calculated by the formula:

$\mathrm{CC}=\mathrm{Xmix} / \mathrm{Xmono},(3)$

where Xmix is the trait value for each variety in the mixture, Xmono is the trait value in pure line. To determine the effects of + or - compensation the plant productivity of variety mixtures was compared with the plant productivity of pure varieties.

Table 1 shows the characteristics of the varieties used in the experiment by yield and the most important quantitative characteristics and indices. By yield, the varieties in descending order were as follows: Levada, Venera, Redut, Dolya. According to other characteristics and indices, the arrangement of varieties was somewhat different (Table 1). Levada was superior to other varieties also in such a valuable traits as productive tillering winter hardiness.

Table 1

Characteristics of winter wheat varieties involved in the study

\begin{tabular}{|c|c|c|c|c|}
\hline \multirow{2}{*}{ Traits and indices } & \multicolumn{4}{|c|}{ Varieties } \\
\cline { 2 - 5 } & Levada & Dolya & Redut & Venera \\
\hline Type & Erithrospermum & Ferrugineum & Erithrospermum & Lutescens \\
\hline Yield, t/ha & 6,18 & 4,12 & 5,45 & 5,94 \\
\hline Vegetation period & middle-ripening & $\begin{array}{c}\text { early- } \\
\text { ripening }\end{array}$ & middle-ripening & $\begin{array}{c}\text { middle- } \\
\text { ripening }\end{array}$ \\
\hline Productive tillering (PT) & 5,1 & 4,3 & 4,3 & 4,1 \\
\hline Plant height (PH), cm & 95 & 89 & 90 & 99 \\
\hline Grain weight /ear (GW), g & 1,6 & 1,2 & 1,6 & 1,6 \\
\hline Stem weight (SW), g & 1,2 & 1,2 & 1,3 & 1,6 \\
\hline $\begin{array}{c}\text { Linear ear density } \\
\text { (LED) }\end{array}$ & 4,3 & 3,9 & 4,4 & 3,9 \\
\hline Poltavskii index (PI) & 5,1 & 4,6 & 3,0 & 5,1 \\
\hline $\begin{array}{c}\text { Winter hardiness, score } \\
\text { from 1 to 9 }\end{array}$ & 9 & 8 & 8 & 7 \\
\hline
\end{tabular}

Table 2 presents results of study of competitiveness of winter wheat varieties in mixtures and pure line by some agronomic parameters and indices.

Grain weight/ear (GW). According to estimation the difference of GW in mixture and pure variety, the lowest-yielding variety Dolya had the highest competitiveness $\Delta \mathrm{Xi}$, and the highest-yielding Levada variety had the least negative competitiveness. Venera's competitiveness ranked second and had a significant excess in GW in mixture compared to pure variety, and Redut showed zero competitiveness, i.e. there was no difference between mixture and pure variety. This result is confirmed by the analysis of $\Delta \mathrm{Xj}$. 
The highest increase in GW of varieties was observed in a mixture with Levada, and the lowest - in mixture with Venera and Dolya.

Table 2

\section{Competitiveness of winter wheat varieties}

by agronomic parameters and indices

\begin{tabular}{|c|c|c|c|c|c|c|}
\hline Variety & Levada & Dolya & Redut & Venera & $\Delta \mathbf{X i}$ & $\Delta \mathbf{X j}$ \\
\hline \multicolumn{7}{|c|}{ Grain weight/ear (GW), g } \\
\hline Levada & 1,6 & 1,6 & 1,4 & 1,6 & $-4,167$ & 20,455 \\
\hline Dolya & 1,5 & 1,2 & 1,5 & 1,4 & 22,222 & 4,167 \\
\hline Redut & 1,8 & 1,6 & 1,6 & 1,4 & 0,000 & 11,364 \\
\hline Venera & 2,0 & 1,8 & 1,8 & 1,6 & 16,667 & 0,000 \\
\hline \multicolumn{7}{|c|}{ Stem weight (SW), g } \\
\hline Levada & 1,2 & 1,2 & 1,0 & 1,2 & $-5,556$ & 19,512 \\
\hline Dolya & 1,4 & 1,2 & 1,4 & 1,2 & 11,111 & 0,454 \\
\hline Redut & 1,6 & 1,4 & 1,3 & 1,2 & 7,672 & 7,500 \\
\hline Venera & 1,9 & 1,7 & 1,9 & 1,6 & 14,583 & 2,703 \\
\hline \multicolumn{7}{|c|}{ Linear ear density (LED) } \\
\hline Levada & 4,3 & 4,3 & 4,6 & 4,6 & 4,651 & 8,197 \\
\hline Dolya & 4,4 & 3,9 & 4,3 & 4,7 & 14,513 & $-0,794$ \\
\hline Redut & 4,4 & 4,2 & 4,4 & 4,0 & $-4,545$ & 7,438 \\
\hline Venera & 4,4 & 4,0 & 4,1 & 3,9 & 6,838 & 5,263 \\
\hline \multicolumn{7}{|c|}{ Poltavskii index (PI) } \\
\hline Levada & 51 & 55 & 49 & 48 & $-0,654$ & 40,945 \\
\hline Dolya & 61 & 46 & 59 & 55 & 26,812 & 26,515 \\
\hline Redut & 57 & 55 & 30 & 43 & 72,222 & 10,135 \\
\hline Venera & 61 & 57 & 55 & 51 & 13,072 & 19,685 \\
\hline \multicolumn{7}{|l|}{ Productive tillering, pc. } \\
\hline Levada & 5,1 & 5,0 & 4,2 & 4,4 & $-11,111$ & 7,087 \\
\hline Dolya & 4,2 & 4,3 & 3,8 & 3,6 & $-10,078$ & 0,000 \\
\hline Redut & 4,7 & 4,5 & 4,3 & 3,7 & 0,000 & $-15,556$ \\
\hline Venera & 4,7 & 4,0 & 3,6 & 4,1 & 0,000 & $-14,599$ \\
\hline
\end{tabular}

Coefficient of competitiveness (CC) had shown that genotypes with $\mathrm{CC}>1$ had increased trait parameters in mixtures in comparison with pure varieties. Genotypes with $\mathrm{CC}<1$, respectively, had reduced trait parameters in mixture compared to pure varieties (Table 3). Thus, varieties Venera and Dolya had a positive competitiveness (>1), and varieties Redut and Levada - negative $(<1)$, that confirmed results from $\Delta \mathrm{Xi}$ and $\Delta \mathrm{Xj}$.

Stem weight $(\mathbf{S W})$. According to estimation the $\Delta \mathrm{Xi}$ and $\Delta \mathrm{Xj}$ values, the highest competitiveness $\Delta \mathrm{Xi}$ was observed in Venera variety; Dolya and Redut varieties also had positive competitiveness. High-yielding variety Levada had as negative competitiveness as in GW. These results are fully confirmed by the results of CC in 4-components mixture. 
Table 3

Coefficient of competitiveness (CC) of winter wheat varieties in 4-components mixture by agronomic parameters and indices

\begin{tabular}{|c|c|c|c|c|c|c|c|c|c|c|c|c|c|c|c|}
\hline \multirow{2}{*}{ 尝 } & \multicolumn{3}{|c|}{ GW } & \multicolumn{3}{|c|}{ SW } & \multicolumn{3}{|c|}{ LED } & \multicolumn{3}{|c|}{ PI } & \multicolumn{3}{|c|}{ PT } \\
\hline & $\stackrel{\star 凶}{\Sigma}$ & $\stackrel{\Xi}{\Xi}$ & U & $\stackrel{k}{\Sigma}$ & $\stackrel{\Xi}{\Xi}$ & U & $\stackrel{x}{\Sigma}$ & $\stackrel{\Xi}{\Xi}$ & U & $\stackrel{x}{\stackrel{x}{z}}$ & $\stackrel{\Xi}{\Xi}$ & U & $\stackrel{\star 凶}{\Sigma}$ & $\stackrel{\Xi}{\Xi}$ & U \\
\hline$\stackrel{*}{\lrcorner}$ & $\stackrel{\Xi}{=}$ & $\stackrel{0}{0}$ & $\begin{array}{l}\infty \\
\infty \\
0\end{array}$ & $\stackrel{.}{-}$ & $\cong$ & $\begin{array}{l}\text { On } \\
0 \\
0\end{array}$ & $\bar{f}$ & $\stackrel{2}{F}$ & $\approx$ & F & $\vec{n}$ & $\hat{\delta}$ & $\stackrel{\infty}{\infty}$ & $\vec{n}$ & $\stackrel{2}{\tilde{o}}$ \\
\hline 药 & $\stackrel{m}{-}$ & $\stackrel{\sim}{=}$ & $\stackrel{\infty}{\circ}$ & $\stackrel{\sim}{=}$ & $\stackrel{\simeq}{=}$ & $\stackrel{0}{-}$ & $\stackrel{\circ}{\circ}$ & $\vec{m}$ & $\stackrel{\tilde{s}}{-}$ & in & $\stackrel{0}{\circ}$ & $\exists$ & $=$ & $\stackrel{?}{*}$ & $\stackrel{2}{0}$ \\
\hline$\stackrel{*}{\simeq}$ & $\because$ & $\stackrel{-}{0}$ & ठே. & 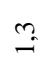 & $\stackrel{2}{=}$ & 요 & $\stackrel{\text { I }}{f}$ & $\stackrel{+}{+}$ & ஃ̊ & F & $\stackrel{\circ}{\circ}$ & in & i & $\stackrel{m}{*}$ & $\begin{array}{c}\text { to } \\
\infty \\
0\end{array}$ \\
\hline$\stackrel{*}{>}$ & i & $\stackrel{0}{-}$ & $\stackrel{2}{\stackrel{2}{\sim}}$ & $\Rightarrow$ & 2 & $\stackrel{\vartheta}{=}$ & $\stackrel{2}{*}$ & ले & 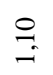 & గु & $\vec{n}$ & $\underset{\sim}{-}$ & $m$ & $\bar{f}$ & $\begin{array}{l}n \\
\infty \\
0\end{array}$ \\
\hline$\gtrless$ & $n$ & $\because$ & $\tilde{\sigma}_{-}$ & $\stackrel{n}{\sim}$ & $\stackrel{m}{m}$ & है & $\stackrel{n}{\underset{f}{f}}$ & $\stackrel{m}{\Rightarrow}$ & $\stackrel{\sigma}{-}$ & $\stackrel{\infty}{\sim}$ & $\stackrel{n}{\stackrel{f}{*}}$ & $\stackrel{0}{=}$ & $\stackrel{n}{\stackrel{n}{m}}$ & $\stackrel{\substack{f \\
f}}{+}$ & $\begin{array}{l}+ \\
\infty \\
0\end{array}$ \\
\hline
\end{tabular}

* L-Levada, D-Dolya, $R-$ Redut, $V$-Venera

Linear ear density (LED). The highest positive competitiveness $\Delta \mathrm{Xi}$ in linear spike density (LED) was in Dolya variety, then Venera and Levada, and the lowest negative competitiveness was in Redut variety. According to the 4-components mixture, the positive CC had varieties Dolya and Venera, and Levada and Redut had negative CC, although the difference between all varieties in mixture and pure varieties was small. In other words, LED has reacted weakly to the presence or absence of genotype competition.

Poltavskii index (PI). A detailed description of this new index is given by, which was successfully used for selection of winter wheat genotypes at early breeding stages. Variety Redut has showed high competitiveness $\Delta \mathrm{Xi}$ by PI in mixture, but in pure variety PI was low (3.0) compared to 4.6 ... 5.1 in other varieties. A negative low $\Delta \mathrm{Xi}$ and high positive $\Delta \mathrm{Xj}$ of PI of Levada variety has indicated the extremely low competitiveness of Levada by this valuable selection index. Varieties Dolya and Venera had a positive average competitiveness $\Delta \mathrm{Xi}$ of PI. This distribution of varieties in diallelic mixtures completely coincides with their assessment in 4-component mixture. On average, the value of PI in mixtures had significantly exceeded pure varieties on $14 \%$. It should be noted that the differences between the varieties by 
competitiveness of Poltavskii index (PI) are more significant than by the parameters discussed above.

Productive tillering (PT). This valuable selection trait was characterized by the fact that all varieties in two-component mixtures turned out to be uncompetitive. A similar and even clearer result was obtained in a 4-component mixture - all 4 varieties had $\mathrm{CC}<1$. On average, the value of PT in mixtures was less than in pure varieties by $18,7 \%$.

Among the 4 winter wheat varieties studied, significant differences were noted in competitiveness. The effect of competition on five traits and indices related to grain productivity was studied. By such parameters as, grain weight / ear (GW), stem weight (SW) and breeding indices (Poltavskii index (PI) and index of linear ear density (LED)), significant differences were noted between varieties competitiveness. According to GW and LED, the most plus-competitiveness was possessed by the lowest-yielding, earlyripening, short-stem variety Dolya; the plus-competitiveness on these traits was shown by the relatively high-yielding variety Venera; the lowest negative competitiveness was observed in the high-yielding variety Levada and medium-yielding variety Redut. Blending of varieties adversely affected the productive tillering of all varieties in which negative competitiveness was observed on this trait.

Overcompensation (+ ; -). The effects of overcompensation were determined by the deviation of the actual yield of mixtures from the theoretical yield, calculated by the average yield of pure varieties. If the actual yield exceeded the theoretical one, it was interpreted as plusovercompensation, and if the actual yield was lower than the theoretical one, then it was attributed to minus-overcompensation. As can be seen from Table 4, in most combinations of mixtures an overcompensation effect was observed, and Levada+Venera mixture had highest yield that was exceeded any pure variety. In comparing the actual yield of mixture with the yield of the best component in mixture, either the absence of reliable overcompensation or the presence of negative over-compensation was recorded.

When comparing actual and theoretical productivity, the positive overcompensation was noted in five combinations of mixtures, and the negative over-compensation was noted only in two combinations. The mutual inhibition of the components was especially strong in the Levada+Redut mixture (- 81.3\%). For practical purposes, only the Levada+Venera combination can be present of certain interest.

It is known that plants with high potential productivity are not sources of highly productive populations, which is due to the effects of intraspecific genotype competition between plants in agrocenosis, which sometimes play a decisive role, but, unfortunately, are often not taken into account in breeding practice, which significantly reduces, and sometimes reduces to zero, the selection efficiency in the early breeding stage. For increasing the efficiency of selection, the main problem is the identification of the genotype 
by phenotype, to solve which it is important to remove the "noise" of environmental and genotypic competition. "Noises" usually mean the variability that prevents extrapolating the productivity of an individual plant in population to the productivity of a unit area of cenosis ${ }^{30}$.

Table 4

Overcompensation effects defined by comparing the yield of varieties in pure line and mixture

\begin{tabular}{|c|c|c|c|c|c|c|}
\hline \multirow{2}{*}{ № } & \multirow{2}{*}{ Mixture of varieties } & \multirow{2}{*}{$\begin{array}{c}\text { Yield of } \\
\text { mixture, } \\
\end{array}$} & & \multicolumn{2}{|c|}{$\begin{array}{c} \pm \text { to the best } \\
\text { variety }\end{array}$} & \multicolumn{2}{|c|}{$\begin{array}{c} \pm \text { to the average } \\
\text { of varieties }\end{array}$} \\
\cline { 4 - 7 } & & t/ha & t/ha & \% & t/ha & \% \\
\hline 1 & Levada + Dolya & 5,58 & $-0,60$ & $-10,8$ & $+0,43$ & $+7,7$ \\
\hline 2 & Levada + Venera & 6,66 & $+0,48$ & $+7,2$ & $+0,60$ & $+9,0$ \\
\hline 3 & Levada + Redut & 3,21 & $-2,97$ & $-92,5$ & $-2,61$ & $-81,3$ \\
\hline 4 & Dolya + Redut & 4,24 & $-1,21$ & $-28,5$ & $-0,55$ & $-13,0$ \\
\hline 5 & Dolya + Venera & 5,94 & 0,0 & 0,0 & $+0,91$ & $+15,3$ \\
\hline 6 & Redut + Venera & 5,88 & $-0,06$ & $-1,0$ & $+0,46$ & $+7,8$ \\
\hline
\end{tabular}

\section{Variability of quantitative traits of winter wheat varieties in mixture and in pure-lines}

This report presents the results of studies of 4 varieties of winter wheat in its pure form and in diallelic mixtures with respect to the average yield of "pure components" and shows the formation of grain quality in component mixtures, which is very important in the milling and baking industries.

In the experiment of this report in pure and competitive mixtures, the yield of varieties was calculated. The highest yield in pure-lines was noted in the variety Radyvonivka, which amounted to $5.93 \mathrm{t} / \mathrm{ha}$. The lowest yield in pure-lines in the experiment was in the variety Sharada, the level of which was $4.37 \mathrm{t} / \mathrm{ha}$, that is, $1.56 \mathrm{t} / \mathrm{ha}$ less than the variety whose yield was maximum.

Table 5

Yield of winter wheat varieties in pure-lines and mixture (t/ha)

\begin{tabular}{|c|c|c|c|c|c|}
\hline Variety & Sharada & Ariivka & Karmelyuk & Radyvonivka & $\begin{array}{c}\text { Mixture of 4 } \\
\text { varieties }\end{array}$ \\
\hline Sharada & 4,37 & 4,60 & 4,33 & 4,70 & 6,37 \\
\hline Ariivka & 4,60 & 4,37 & 4,80 & 4,97 & 6,37 \\
\hline Karmelyuk & 4,33 & 4,80 & 5,67 & 5,10 & 6,37 \\
\hline Radyvonivka & 4,70 & 4,97 & 5,10 & 5,93 & 6,37 \\
\hline
\end{tabular}

A high level of productivity was noted in mixtures (Radyvonivka + Karmelyuk) -5.10 t/ha; (Radyvonivka + Ariivka) -4.97 t/ha; (Karmelyuk + Ariivka) - $4.80 \mathrm{t} / \mathrm{ha} ;$ (Sharada + Ariivka) - $4.60 \mathrm{t} / \mathrm{ha}$; (Sharada + Radyvonivka) $-4.70 \mathrm{t} / \mathrm{ha}$. In the experiment, such a feature was noted that

30 Essah S.Y.C., Stoskopf N.C. Mixture performance of phenotypically contrasting barley cultivars. Can. J. Plant Sci. 2001. № 82. P. 1-6. 
some varieties in mixtures increased the yield by experience, and in some they decreased. So, the varieties Sharada, Ariivka in mixtures: Sharada + Ariivka; Sharada + Radyvonivka; Ariivka + Karmelyuk; Ariivka + Radyvonivka increased productivity according to the pure-lines, and in mixtures Karmelyuk + Sharada; Karmelyuk + Ariivka; Karmelyuk + Radyvonivka, on the contrary, yield according to the pure-lines decreased.

Plus compensation in relation to the average yield of "pure components" was observed in four mixes, with an excess of 0.44 to $2.00 \mathrm{t} / \mathrm{ha}$. The results of plus compensation can be used both in the practical cultivation of varieties-mixtures (Sharada; Ariivka; Karmelyuk; Radyvonivka), and to create multi-linear varieties. We believe that with the involvement of a wider range of varieties and breeding lines of winter wheat in the study, it is possible to select components for mixtures that provide increased yield, crop stability and higher grain quality.

One of the main traits of the yield potential is the grain weight per ear. In the experiment, the level of formation of this trait ranged from $1.18 \mathrm{~g}$ (Charada + Ariivka) to 1.26 (Sharada + Karmelyuk) (Table 6). Only 2 cases were noted when a decrease in grain weight was observed in 2 component mixtures (Sharada + Ariivka) and 4 component mixtures (Sharada + Ariivka + Radyvonivka + Karmelyuk) by $0.9 \pm 0.4 \mathrm{~g}$, and in other cases it increased in relation to pure-lines.

Table 6

Variability of productivity parameters of winter wheat variety Sharada in pure-line and in mixtures

\begin{tabular}{|c|c|c|c|c|c|}
\hline Parameters & $\begin{array}{c}\text { Sharada } \\
\text { pure-line }\end{array}$ & $\begin{array}{c}\text { Sharada }+ \\
\text { Ariivka }\end{array}$ & $\begin{array}{c}\text { Sharada }+ \\
\text { Karmelyuk }\end{array}$ & $\begin{array}{c}\text { Sharada + } \\
\text { Radyvonivka }\end{array}$ & $\begin{array}{c}\text { 4-varieties } \\
\text { mixture }\end{array}$ \\
\hline Y( t/ha)* & 4,37 & 4,33 & 4,80 & 5,10 & 6,37 \\
\hline H $(\mathrm{sm})$ & $74,8 \pm 1,4$ & $72,5 \pm 0,8$ & $66,9 \pm 1,6$ & $69,4 \pm 1,1$ & $72,2 \pm 1,2$ \\
\hline TSI & $3,4 \pm 0,1$ & $3,5 \pm 0,1$ & $3,4 \pm 0,1$ & $3,4 \pm 0,1$ & $3,2 \pm 0,1$ \\
\hline EL & $4,9 \pm 0,1$ & $4,9 \pm 0,1$ & $4,9 \pm 0,1$ & $4,9 \pm 0,1$ & $4,6 \pm 0,1$ \\
\hline SE & $16,3 \pm 0,3$ & $17,1 \pm 0,3$ & $17,5 \pm 0,2$ & $17,2 \pm 0,3$ & $16,3 \pm 0,3$ \\
\hline GW & $1,21 \pm 0,1$ & $1,18 \pm 0,01$ & $1,26 \pm 0,03$ & $1,24 \pm 0,01$ & $0,90 \pm 0,04$ \\
\hline GE & $37,4 \pm 1,6$ & $39,8 \pm 1,6$ & $39,5 \pm 1,0$ & $39,6 \pm 1,1$ & $30,6 \pm 1,3$ \\
\hline TGW & $32,2 \pm 0.6$ & $29,8 \pm 0,8$ & $31,8 \pm 0,6$ & $31,6 \pm 0,8$ & $29,5 \pm 1,2$ \\
\hline
\end{tabular}

$* Y-, t / h a ; H$ - plant height, sm; TSI - thickness of the second internode, mm; EL-ear length, sm; $S E$ - number of spikelets per ear, pc.; GW-grains weight per ear, g; GE-grain number per ear, pc.; TGW-thousand grains weight, $g$

For the Ariivka variety, a decrease in this trait was noted in almost all component mixtures provided for in the experiment by grain weight. If in pure-line it was $2.6 \pm 0.1 \mathrm{~g}$, then in other component mixtures, a tendency to decrease was noted (Table 7).

According to Karmelyuk variety, the level of grain weight formation per ear in pure-line was $1.5 \pm 0.1 \mathrm{~g}$, and in 2-component mixtures (Karmelyuk + Sharada) this indicator increased to the level of $1.7 \pm 0.1 \mathrm{~g}$ (Table 8). 
In 2-component mixtures (Karmelyuk + Radyvonivka) the value of this trait decreased by a small percentage. We explain the increase in grain weight in the 2-component mixture (Karmelyuk + Sharada) by the difference in plant height, that is, in this mixture, obviously, there was more lighting for Karmelyuk and it formed a high level of stem weight.

Table 7

Variability of productivity parameters of winter wheat variety Ariivka in pure-line and in mixtures

\begin{tabular}{|c|c|c|c|c|c|}
\hline Parameters & $\begin{array}{c}\text { Ariivka } \\
\text { pure-line }\end{array}$ & $\begin{array}{c}\text { Ariivka } \\
\text { +Sharada }\end{array}$ & $\begin{array}{c}\text { Ariivka + } \\
\text { Karmelyuk }\end{array}$ & $\begin{array}{c}\text { Ariivka + } \\
\text { Radyvonivka }\end{array}$ & $\begin{array}{c}\text { 4-varieties } \\
\text { mixture }\end{array}$ \\
\hline Y( t/ha)* & 4,37 & 4,60 & 4,80 & 4,97 & 6,37 \\
\hline H $(\mathrm{sm})$ & $77,9 \pm 1,1$ & $83,7 \pm 0,8$ & $80,8 \pm 1,2$ & $84,2 \pm 1,9$ & $80,4 \pm 1,2$ \\
\hline TSI & $4,2 \pm 0,1$ & $4,0 \pm 0,1$ & $4,1 \pm 0,1$ & $3,9 \pm 0,1$ & $3,5 \pm 0,1$ \\
\hline EL & $8,6 \pm 0,1$ & $8,4 \pm 0,1$ & $8,3 \pm 0,1$ & $8,6 \pm 0,2$ & $8,4 \pm 0,2$ \\
\hline SE & $20,3 \pm 0,2$ & $20,4 \pm 0,3$ & $19,6 \pm 0,3$ & $19,2 \pm 0,3$ & $18,1 \pm 0,4$ \\
\hline GW & $2,6 \pm 0,1$ & $2,4 \pm 0,1$ & $2,3 \pm 0,1$ & $2,2 \pm 0,1$ & $2,02 \pm 0,1$ \\
\hline GE & $62,5 \pm 1,6$ & $58,7 \pm 1,3$ & $56,7 \pm 1,6$ & $55,9 \pm 2,1$ & $51,8 \pm 2,1$ \\
\hline TGW & $41,1 \pm 0,8$ & $40,9 \pm 0,9$ & $40,01 \pm 0,8$ & $39,9 \pm 0,9$ & $38,7 \pm 1,01$ \\
\hline
\end{tabular}

Table 8

Variability of productivity parameters of winter wheat variety Karmelyuk in pure-line and in mixtures

\begin{tabular}{|c|c|c|c|c|c|}
\hline Parameters & $\begin{array}{c}\text { Karmelyuk } \\
\text { pure-line }\end{array}$ & $\begin{array}{c}\text { Karmelyuk } \\
\text { +Sharada }\end{array}$ & $\begin{array}{c}\text { Karmelyuk } \\
\text { + Ariivka }\end{array}$ & $\begin{array}{c}\text { Karmelyuk + } \\
\text { Radyvonivka }\end{array}$ & $\begin{array}{c}\text { 4- } \\
\text { varieties } \\
\text { mixture }\end{array}$ \\
\hline Y(t/ha)* & 5,67 & 4,33 & 4,80 & 5,10 & 6,37 \\
\hline H (sm) & $80,02 \pm 2,8$ & $86,0 \pm 1,0$ & $93,3 \pm 1,0$ & $95,2 \pm 1,6$ & $91 \pm 1,5$ \\
\hline TSI & $3,4 \pm 0,1$ & $3,3 \pm 0,1$ & $3,4 \pm 0,1$ & $3,4 \pm 0,1$ & $3,5 \pm 0,1$ \\
\hline EL & $7,9 \pm 0,1$ & $7,7 \pm 0,1$ & $7,6 \pm 0,1$ & $7,3 \pm 0,1$ & $7,7 \pm 0,1$ \\
\hline SE & $16,9 \pm 0,3$ & $17,2 \pm 0,2$ & $17,0 \pm 0,3$ & $16,2 \pm 0,3$ & $17,2 \pm 0,2$ \\
\hline GW & $1,5 \pm 0,1$ & $1,7 \pm 0,1$ & $1,5 \pm 0,1$ & $1,3 \pm 0,1$ & $1,6 \pm 0,06$ \\
\hline GE & $40,6 \pm 1,5$ & $42,7 \pm 1,1$ & $39,6 \pm 1,3$ & $34,3 \pm 1,5$ & $40,6 \pm 1,3$ \\
\hline TGW & $37,7 \pm 1,1$ & $40,7 \pm 0,9$ & $38,3 \pm 0,8$ & $37,9 \pm 0,9$ & $39,3 \pm 0,6$ \\
\hline
\end{tabular}

The level of formation of the trait "grain weight per ear" in a pure-line Radyvonivka was $2.2 \pm 0.1 \mathrm{~g}$ and in mixtures in only one case (Radyvonivka + Sharada) the level of grain weight per ear increased, and in other cases, this indicator decreased in relation to pure-line (Table 9).

The number of grains per ear is one of the main traits of the formation of the yield potential of winter wheat varieties. In the experiment, the level of formation of this trait in Sharada was $37.4 \pm 0.6 \mathrm{~g}$ relative to pure-line, and in 2-component mixtures this indicator increased to the level of $39.8 \pm 1.6 \mathrm{~g}$. It should be noted that in the 4-component mixture, there was a sharp decrease in the number of grains per ear to $30.6 \pm 1.3 \mathrm{~g}$. 
Table 9

Variability of productivity parameters of winter wheat variety Radyvonivka in pure-line and in mixtures

\begin{tabular}{|c|c|c|c|c|c|}
\hline Parameters & $\begin{array}{c}\text { Radyvonivka } \\
\text { pure-line }\end{array}$ & $\begin{array}{c}\text { Radyvonivka } \\
\text { +Sharada }\end{array}$ & $\begin{array}{c}\text { Radyvonivka } \\
\text { + Ariivka }\end{array}$ & $\begin{array}{c}\text { Radyvonivka } \\
\text { + Karmelyuk }\end{array}$ & $\begin{array}{c}\text { 4-varieties } \\
\text { mixture }\end{array}$ \\
\hline Y(t/ha)* & 5,93 & 4,70 & 4,97 & 5,10 & 6,37 \\
\hline H (sm) & $94,4 \pm 1,0$ & $96,3 \pm 0,7$ & $97,0 \pm 1,0$ & $104,8 \pm 0,9$ & $101 \pm 1,4$ \\
\hline TSI & $3,8 \pm 0,1$ & $4,01 \pm 0,1$ & $3,7 \pm 0,1$ & $3,8 \pm 0,1$ & $3,8 \pm 0,04$ \\
\hline EL & $9,1 \pm 0,2$ & $9,04 \pm 0,1$ & $8,2 \pm 0,2$ & $8,2 \pm 0,2$ & $8,0 \pm 0,1$ \\
\hline SE & $18,8 \pm 0,3$ & $19,2 \pm 0,3$ & $17,8 \pm 0,3$ & $17,5 \pm 0,3$ & $17,5 \pm 0,2$ \\
\hline GW & $2,2 \pm 0,1$ & $2,3 \pm 0,1$ & $1,9 \pm 0,1$ & $1,8 \pm 0,1$ & $1,7 \pm 0,05$ \\
\hline GE & $49,4 \pm 1,6$ & $52,2 \pm 1,8$ & $46,1 \pm 1,7$ & $42,5 \pm 1,9$ & $41,3 \pm 1,3$ \\
\hline TGW & $45,5 \pm 0,8$ & $44,8 \pm 0,8$ & $40,7 \pm 0,8$ & $42,9 \pm 0,7$ & $42,0 \pm 0,5$ \\
\hline
\end{tabular}

In 4-component mixtures, the number of grains per ear in Karmelyuk variety in relation to pure-line was stable and amounted to $40.6 \pm 1.5 \mathrm{~g}$, and in 2-component mixtures (Karmelyuk + Sharada) we observed an increase in the trait to $42.7 \pm 1.1 \mathrm{~g}$., in 2 other cases, a decrease in the trait was observed in relation to pure-line $-34.3 \pm 1.5 \mathrm{~g}$.

For Radyvonivka variety, the number of grains per ear decreases in relation to pure-line from $49.4 \pm 1.6 \mathrm{~g}$ to $41.3 \pm 1.3 \mathrm{~g}$, except for 2-component mixtures (Radyvonivka + Sharada) where the trait was 52, $2 \pm 1.8$.

Grain quality of winter wheat varieties in competitive mixtures

Grain quality of winter wheat is the main criterion for evaluating the variety and therefore has a direct relationship with the traits of grain productivity.

In the CIS countries, three groups of soft wheat are distinguished by the technological properties of grain: strong, valuable and weak. Strong wheat contains the maximum amount of protein (at least 14\%) and high-quality gluten $(28 \%$ with Index of gluten deformation $=45-75)$, forms a dough that can withstand intensive kneading and prolonged fermentation, provides a high volume of bread.

Valuable wheat gives good quality bread, but they can not be improvers. The three quality groups of winter wheat varieties - strong, valuable and filler - since 2003 added a group of superstrong wheat with specific physical and technological parameters of grain quality, the first of which was the Panna variety, obtained by crossing the highly winter-resistant Odom variety with the high-quality Odesska chervonokolosa variety.

Such high grain quality parameters as Panna have only Canadian spring wheat variety Glen Lea. Panna differs from all other varieties of strong wheat in the presence of four new for Ukraine alleles of the storage proteins Gld 1A10, Gld 1B15, Gld 6B4 and Glt 1B5 and a sufficiently high resistance to grain germination in ear at the final stage of maturation.

The objective of the experiment was also to investigate the level of grain quality formation of the studied varieties of winter wheat. We included two parameters in the grain quality: the protein content (\%) and gluten content 
(\%). According to the analysis data (Table 10), in terms of protein content, the Sharada variety in the experiment with 2-component mixtures formed an increased protein content from 15.2 to 16.2 in relation to pure-line, and a decrease in protein content by a slight percentage in relation to pure-line.

Table 10

Protein content of winter wheat varieties in mixture, $\%$

\begin{tabular}{|c|c|c|c|c|c|}
\hline Variety & Sharada & Ariivka & Karmelyuk & Radyvonivka & $\begin{array}{c}\text { 4-varieties } \\
\text { mixture }\end{array}$ \\
\hline Sharada & 16,1 & 15,2 & 16,2 & 16,0 & 15,5 \\
\hline Ariivka & 13,6 & $\mathbf{1 3 , 7}$ & 14,3 & 13,6 & 14,7 \\
\hline Karmelyuk & 12,2 & 12,4 & $\mathbf{1 2 , 3}$ & 12,7 & 13,3 \\
\hline Radyvonivka & 13,7 & 13,0 & 12,0 & $\mathbf{1 4 , 6}$ & 12,1 \\
\hline Mean & & & & & 13,9 \\
\hline
\end{tabular}

In the experiment, in relation to pure-line in 2-component mixtures, the Ariivka variety reduced the protein content to 13.6, and only in the Karmelyuk + Ariyevka mixture did it increase from 13.7 to 14.3. Karmelyuk in the experiment in 2-component mixtures increased the protein content in relation to pure-line, and in the mixture (Sharada + Karmelyuk) there was a decrease to 12.2. It should be noted that in the 4-component mixture, the Karmelyuk variety formed the highest protein content, and the Radyvonivka variety in the experiment on the protein content in all mixtures reduced the protein content in relation to pure-line from 14.6 to $12.0 \%$.

In the experiment on gluten content (Table 11), pure-line varieties had a high gluten content, and in mixtures this parameter decreased. So, for Sharada, the gluten content in pure-line was $35.0 \%$ and in 2-component mixtures (Ariivka + Sharada) $-33.3 \%$, in 4 -components mixture $-33.7 \%$.

Table 11

Gluten content of winter wheat varieties in mixtures, \%

\begin{tabular}{|c|c|c|c|c|c|}
\hline Variety & Sharada & Ariivka & Karmelyuk & Radyvonivka & $\begin{array}{c}\text { 4-varieties } \\
\text { mixture }\end{array}$ \\
\hline Sharada & $\mathbf{3 5 , 0}$ & 33,3 & 37,0 & 35,7 & 33,7 \\
\hline Ariivka & 30,0 & $\mathbf{2 9 , 0}$ & 30,5 & 29,1 & 31,8 \\
\hline Karmelyuk & 24,6 & 25,3 & $\mathbf{2 5 , 8}$ & 26,9 & 28,3 \\
\hline Radyvonivka & 28,9 & 27,2 & 24,3 & $\mathbf{3 1 , 3}$ & 25,2 \\
\hline Mean & & & & 29,7 \\
\hline
\end{tabular}

It should be noted that in Ariivka variety, in the experiment on the gluten content in all mixtures, an increase in this parameter with respect to pureline from 29.0 to $31.8 \%$ was observed. And in the varieties Karmelyuk and Radyvonivka, on the contrary, a decrease in this parameter was observed in relation to pure-line. 


\section{Indirect methods for estimation of winter wheat lines and varieties}

The left-bank forest-steppe Ukraine is major producer of winter wheat. It is characterized by continental climate with frost winters, spring delays, and summer droughts and in whole by very unstable environmental conditions. Therefore the winter wheat grain production varies by years. The main causes of this are low resistance to frost and others abiotic and biotic factors. In Poltava region the modern commercial cultivars of Ukrainian and Russian breeding are cultivated and characterized by high productivity but low frost resistance. The creation of new intensive cultivars, with adaptation to the forest-steppe climate varying, demands special approaches to winter wheat breeding programs. A new program of selection and genetic research has been developed in our centre since 1999 based on ecological and genetic approach. It is aimed at creating cultivars with improved parameters of yield, quality, adaptability and other useful characteristics. For the purpose of improvement of breeding process the method of indirect estimation of accessions is applied. The traits and indexes that have close genetic correlations with productivity traits are used for selection of accessions at early stages of breeding. The selection of accessions by desirable parameters is provided by cluster analysis. The application of indirect selection on the early winter wheat breeding by optimal combinations of useful traits in one genotype will provide effective breeding for high spike productivity.

Winter wheat is characterized by autumn-winter-spring environment factors that influence on productivity: frost resistance, presence of genes of sensibility to photoperiod, necessity of definite duration of vernalization, "per se" genes and others. The level of adaptation of wheat plant to limited environment factors is defined by photoperiodic sensibility and duration of vernalization period. The new estimation procedure of photoperiodic sensibility with the using of three autumn sowing dates: early, optimal and late has been implemented in our breeding practice.

For detection of necessity definite duration of vernalization period for different lines and cultivars the method of artificial delay of spring vegetation (Medinetz method) is actively used. Genotype differences between lines generally are reflected in the number of plants which survived and on productivity accordingly. This method allows choosing genotypes and selecting accessions by the level of photoperiodic sensitivity and duration of vernalization period for specific environmental conditions. The technology of individual and family selection under limiting environmental factors became promising way of plant breeding.

The elaboration and application these new approaches in winter wheat breeding allow the little team of our breeding centre during a short time to create unique breeding material, 14 cultivars which are in National Catalogue and characterized by high adaptive properties, grain quality and productivity. 
Every year 300-350 accessions of winter wheat and others crops are multiplied and studied. In our collections the main place is held by the donors and sources of special useful characteristics such as resistance to pathogen race, morphological traits, resistance to unfavorable environmental factors (frost and drought resistance of winter wheat cultivars) and others. Some of cultivars, that are cultivated now, were created using the accessions of world genetic collection in hybridizations. For example, winter wheat Levada was created by step hybridization of Ukrainian cultivar Mironovskaya 808 with Bulgarian Pliska and the obtained line 140 was crossed with modern Ukrainian cultivar Albatros odesskiy.

Global climate changes exert influence on winter wheat cultivation, main cereal of left-bank forest-steppe Ukraine. This region is characterized by instability of weather conditions, especially in autumn-winter-spring period. Thus to get the stable yield each year independently of winter conditions it is necessary to use winter wheat varieties which are characterized by high level of adaptation. With this aim in our Research Plant Breeding Centre the breeding program of the creation of productivity winter wheat cultivars with great winter resistance is developed.

First in Poltava region conditions the methods of winter hardiness estimation of winter wheat varieties and lines have been elaborated and implemented. It has been proposed that the main components in winter hardiness are photoperiodic sensibility and vernalization period. One of the methods is the using different sowing term and the analysis of photoperiodic sensibility of plants. Another is the analysis of vernalization period duration in conditions of hand-made delay of vegetation in spring time. Genotype differences between lines generally are reflected in the number of plants which survived and on productivity accordingly.

The researches according to indirect methods of winter hardiness estimation have been carried out at Poltava State Agrarian Academy during last 20 years. The method of indirect estimation of photoperiodic sensibility (PPS) and duration of vernalization period (DVP) were developed. The basis of PS estimation is sowing terms and the basis of DVP estimation is the time of renewal spring vegetation.

Winter wheat varieties significantly are different according to duration of vernalization period from 15 to 60 days and more. It is known that demand in DVP is controlled by genes $V r d l$ and $V r d 2$ and less demand in DVP predominates (20-30 days) (Fayt, 2003). On the other hand photoperiodic sensibility is controlled by genes $P p d 1 \ldots 3$, dominant alleles of these genes determine neutral and weak PPS, and recessive alleles determine strong PPS (long-day varieties).

PPS and DVP define significantly the level of plant adaptation to growing conditions and especially to wintering. The differences between genotypes by these signs (PPS and DVP) appear at early developmental stages of plant. Thus, the strong PPS and long DVP delay development of 
rudiments of reproductive organs during autumn period and increase the resistance level to stress environment factors in wintering. The weak PPS and short DVP, vice versa accelerate development but in this case plants perish from the frost although these plants are characterized by rapid spring aftergrowing.

The method of photoperiodic reaction testing winter wheat cultivars is rather complicated under laboratory conditions and expensive. We use simpler method of reaction testing by means of yield according to different sowing terms.

One of the main methods of our breeding is index method. Besides, the registration of main quality and quantity traits the accessions are estimating by the values of relative traits, or indexes. The index is a complex notion where the numerator is often some component of productivity and the denominator is the component of vegetative part. Our investigations showed that harvest index (HI), attraction index (AI), microdistribution (MDI), Poltavskiy index (our elaboration) (PI) are the most suitable for using on early breeding of winter wheat. These indexes have a high genetic correlation coefficient with yield per unit of area as compared with grain weight per plant and high heritability coefficient $(74-76 \%$ beside $42 \%$ by grain weight per spike).

The varieties of Research Plant Breeding Centre of Poltava State Agrarian Academy (RPBC PSAA) and some others Ukrainian cultivars, in general 17 varieties were involved in this experiment. The experimental fields located in Poltava region, Forest-Steppe zone of Ukraine.

Two sowing terms were used for studying the photoperiodic sensibility of given varieties: the $1^{\text {st }}$ term is early term - September 1 ; the $2^{\text {nd }}$ term is late term-October1. The optimal sowing term for winter wheat in this region is from September15 till September 25.

For studying the necessity of vernalization period duration of different varieties, Medinetz's method has been used. According to this method handmade snow cover is created which delay the renewal time of spring vegetation.

Hand-made snow cover was removed for two times: 17 April and 25 April. Then the number of survived plants on the $15^{\text {th }}$ and the $30^{\text {th }}$ day after the beginning of vegetation was calculated. Optimal term of the beginning of spring vegetation in this region is from 15 March till 25 March.

Investigated varieties according to different sowing terms are divided to three groups (Table 12). Varieties of group 1 showed high yield in both sowing terms and it means that these varieties are very sensitive to photoperiod. Kryzhynka variety is characterized by high sensitiveness in our experiment. These varieties don't overgrow under early sowing terms. This feature is very important for producers especially under conditions of moisture lack during autumn period. 
Varieties of the group 2 showed a low yield under the early sowing term and a high yield under the late sowing term and these varieties are genotypes with weak or neutral PPS. These varieties also overgrow during autumn period, accumulate less sugar in leaves, thin out during winter thaw and low temperatures in spring. Under such weather conditions varieties of group 2 lose winter-hardiness and correspondingly have low yield.

Varieties of the group 3 showed a high yield under the early sowing term however under late sowing term can show as well high or lowered yield. These varieties are sensitive to PPS and middle DVP. Winter wheat varieties of this group (early sowing term) attract attention for climatic zones with very instable weather conditions. These varieties intensive grow in spring, it is very important under insufficient moisture during the period "the beginning of spring vegetation - ear formation". During autumn period these varieties are characterized with intensive root system growth on the background weak development of aboveground part. These varieties are winter-hardy and actively use winter moisture through well-developed root system and that is why are able to form high yield.

Winter wheat varieties of Research Plant Breeding Centre of Poltava State Agrarian Academy (RPBC PSAA) according to the results are varieties which have middle and heightened sensibility to PPS. The yield of given varieties don't depend on sowing terms.

Table 12

Yield of winter wheat cultivars subject to sowing terms

\begin{tabular}{|c|c|c|c|}
\hline \multirow{2}{*}{ Varieties } & \multicolumn{2}{|c|}{ Yield, c/ha } & \multirow{2}{*}{$\begin{array}{c}\text { Photoperiodic } \\
\text { sensibility }\end{array}$} \\
\cline { 2 - 3 } & $\begin{array}{c}\text { I sowing term } \\
\text { (September1) }\end{array}$ & $\begin{array}{c}\text { II sowing term } \\
\text { (October1) }\end{array}$ & neutral \\
\hline Vdala & 31,7 & 43,3 & neutral \\
\hline Dovira & 38,3 & 56,7 & neutral \\
\hline Vita & 41,7 & 53,3 & neutral \\
\hline Elegia & 41,7 & 60,0 & neutral \\
\hline Ermak & 41,7 & 63,3 & mid-sensitive \\
\hline Odeska 267 & 51,7 & 55,0 & mid-sensitive \\
\hline Albatros odeskiy & 50,0 & 58,3 & mid-sensitive \\
\hline Mironivska 68 & 63,3 & 61,7 & mid-sensitive \\
\hline Kryzhynka & 68,3 & 70,0 & mid-sensitive \\
\hline Kolomak 5 & 46,7 & 65,0 & mid-sensitive \\
\hline Ukrainka poltavska & 55,0 & 65,0 & mid-sensitive \\
\hline Levada & 55,0 & 71,7 & mid-sensitive \\
\hline Dykanka & 53,3 & 76,7 & mid-sensitive \\
\hline Govtva & 60,0 & 66,7 & mid-sensitive \\
\hline Sidor Kovpak & 50,0 & 76,7 & mid-sensitive \\
\hline Vilshana & 48,3 & 58,3 & 76,7 \\
\hline Sagaydak & 63,3 & \multicolumn{2}{|c}{}
\end{tabular}


The determination of demand in DVP in winter wheat varieties was carried out according to V. Medinezt's method of keeping hand-made snow cover.

It has been established that varieties which showed high percentage survived plants on the $30^{\text {th }}$ day after removing snow cover are characterized elongated DVP. Those varieties which showed total plant loss on the $30^{\text {th }}$ day is characterized by short DVP. The cultivars which showed $50 \%$ of survived plants are characterized by middle period of vernalization. The table 12 demonstrates that varieties with neutral PPS demand the short vernalization period. Whereas sensitive PPS varieties demand middle and elongated vernalization period.

To confirm the conclusions about demands in DVP we calculate additionally the number of full ears. Such indirect method of estimation of demand in DVP presents a view of influence of vernalization period on productivity (table 13).

Table 13

\section{Indirect estimation of DVP by full ear number after forced delay of spring vegetation}

\begin{tabular}{|c|c|c|c|}
\hline \multirow{2}{*}{ Varieties } & \multicolumn{3}{|c|}{ The number of ears } \\
\cline { 2 - 4 } & \multirow{2}{*}{$\begin{array}{c}\text { Natural } \\
\text { condition }\end{array}$} & Delay of vegetation \\
\cline { 2 - 4 } & 283,8 & $217,8(76,7)$ & 178,2 \\
\hline Albatros odeskiy & 330,0 & $323,4(98,0)$ & 224,4 \\
\hline Kolomak 3 & 360,0 & $330,8(91,9)$ & 204,6 \\
\hline Kolomak 5 & 363,0 & $290,4(80,0)$ & 145,2 \\
\hline Ukrainka poltavska & 343,2 & $250,8(73,0)$ & 138,6 \\
\hline Levada & 448,8 & $369,6(82,4)$ & 171,8 \\
\hline Dykanka & 330,0 & $217,8(66,0)$ & 151,8 \\
\hline Manjelia & 448,8 & $277,2(61,8)$ & 151,8 \\
\hline Govtva & 440,0 & $270,2(61,4)$ & 160,8 \\
\hline Sidor Kovpak & 290,4 & $264,0(90,9)$ & 151,8 \\
\hline Vilshana & 310,2 & $297,0(95,7)$ & 231,0 \\
\hline Sagaydak & & & \\
\hline
\end{tabular}

All given varieties showed the high percentage of survived plants after delay vegetation till 17 April (from $61 \%$ to $98 \%$ ). Thus these varieties need the middle or elongated vernalization period.

Because of unfavourable climatic conditions during autumn-winterspring period the special method of determination of winter hardiness of winter wheat varieties and lines is used in our Centre. The sign of winter hardiness was divided into such components as PPS and DVP.

The yield estimation of varieties according to different sowing terms and forced delay of spring vegetation give possibilities to select genotypes and estimate lines and varieties using the level of PPS and DVP for special weather conditions. The estimation of winter hardiness for winter wheat varieties of PSAA breeding is given. It has been established that Poltava 
winter wheat varieties (Levada, Dykanka, Ukrainka poltavska, Manjelia, Sagaidak, Govtva, Vilshana, Sidor Kovpak) have long vernalization period and strict photoperiodic sensibility. It allow to solve the problem of winter wheat plant outgrowing in autumn and save plants under ice crust and in the period of thaw in winter and in low temperature in early spring. In years with unfavorable weather conditions for winter wheat growing and development (low temperatures and long-term ice crust) these varieties showed sufficiently high level of winter resistance.

\section{CONCLUSIONS}

Among the 4 winter wheat varieties studied, significant differences were noted in competitiveness. The effect of competition on five traits and indices related to grain productivity was studied. By such parameters as, grain weight / ear (GW), stem weight (SW) and breeding indices (Poltavskii index (PI) and index of linear ear density (LED)), significant differences were noted between varieties competitiveness. According to GW and LED, the most plus-competitiveness was possessed by the lowest-yielding, earlyripening, short-stem variety Dolya; the plus-competitiveness on these traits was shown by the relatively high-yielding variety Venera; the lowest negative competitiveness was observed in the high-yielding variety Levada and medium-yielding variety Redut. Blending of varieties adversely affected the productive tillering of all varieties in which negative competitiveness was observed on this trait.

Overcompensation, or excess of actual productivity over theoretical, i.e. over the average yield of pure varieties, it demonstrated itself differently depending on mixtures of certain varieties. According to the best-yielding variety, in only one case out of six (Levada $x$ Venera) the plusovercompensation was noted; according to the average yield of pure varieties plus-compensation in four variants of mixtures was observed.

The data on variety competitive interaction in winter wheat with certain assumptions, due to the limited set of genotypes in this experiment, can be used to increase the selection efficiency in the early stages of breeding, because a mixture of varieties imitates a hybrid nursery with a wide range of genotypes represented in it. The obtained results do not make it possible to make reliable conclusions about the negative or positive relationship between competitiveness and productivity or trait value.

The phenomenon of overcompensation can be used both in the practical cultivation of mixtures of varieties, and to create multi-line varieties. With the involvement of a wider range of varieties and lines of winter wheat into the study, it is possible to select components for mixtures that provide increased productivity and yield stability.

The application of indirect estimation methods in plant breeding has given us opportunity to select genotypes according the level of photoperiodic sensibility and duration of vernalization period for special weather 
conditions. It has been established that Poltava winter wheat varieties (Levada, Dykanka, Ukrainka poltavska, Manjelia, Sagaidak, Govtva, Vilshana, Sidor Kovpak) have long vernalization period and strict photoperiodic sensibility. It allow to solve the problem of winter wheat plant outgrowing in autumn and save plants under ice crust and in the period of thaw in winter and in low temperature in early spring. In years with unfavorable weather conditions for winter wheat growing and development (low temperatures and long-term ice crust) these cultivars showed sufficiently high level of winter resistance.

\section{SUMMARY}

This study was aimed to investigate the possibility of realization of productivity by wheat plants in conditions of intraspecific genotypic competition. Four winter wheat varieties were studied in two- and fourcomponent mixtures for effect of competition on yield, some agronomic traits and indices. Significant differences were noted between varieties competitiveness by such parameters as, grain weight per ear, stem weight and breeding Poltavskii index and index of linear ear density.

\section{REFERENCES}

1. Bonjean, A.P., Angus, W.J. The world wheat book. A history of wheat breeding. Paris : Laroisier Publishing and Andover: Intercept. 2001. 1131 p. DOI 10.1006/anbo.2001.1537

2. Faraji, J. Wheat cultivar blends: A step forward to sustainable agriculture. African Journal of Agricultural Research. 2011. № 6(33). P. 6780-6789.

3. Cowger, C., Weisz, R. Winter wheat blends (mixtures) produce a yield advantage in North Carolina. Agronomy Journal. 2008. № 100(1). P. 169-177. DOI 10.2134/agronj2007.0128

4. Finckh, M.R., Gacek, E.S., Goyeau, H., Lannou, C., Merz, U., Mundt, C.C., Munk, L., Nadziak, J., Newton, A.C., de Vallavieille-Pope C., Wolfe M.S. Cereal cultivar and species mixtures in practice. Agronomie: Plant Genetics and Breeding. 2000. № 20. P. 813-837.

5. Wolfe, M.S. Variety mixtures in theory and practice. Scottish Crop Res. Inst., Invergowrie, Dundee, Scotland. 2001. URL: http://www.scri.sari.ac.uk/TiPP/Mix/Booklet/default.htm (assessed 26 June 2007; verified 23 Oct. 2007).

6. Cowger, C., Mundt, C.C. Effects of wheat cultivar mixtures on epidemic progression of Septoria tritici blotch and pathogenicity of Mycosphaerella graminicola. Phytopathology. 2002. № 92. P. 617-623. DOI 10.1094/PHYTO.2002.92.6.617

7. Mundt, C.C. Use of multiline cultivars and cultivar mixtures for disease management. Annu. Rev. Phytopathol. 2002. № 40. P. 381-410. 
8. Newton, A.C., Hackett, C.A., Swanston, J.S. Analysing the contribution of component cultivars and cultivar combinations to malting quality, yield and disease in complex mixtures. Journal of the Science of Food and Agriculture. 2008. № 88. P. 2142-2152.

9. Newton, A.C., Guy, D.C. The effects of uneven, patchy cultivar mixtures on disease control and yield in winter barley. Field Crops Research. 2009. № 110. P. 225-228.

10. Andrew, I.K.S., Storkey, J., Sparkes, D.L. A review of the potential for competitive cereal cultivars as a tool in integrated weed management. Weed Res. 2015. 55, № (3). P. 239-248. DOI 10.1111/wre.12137

11. Andrew, I.K.S., Storkey, J. Using simulation models to investigate the cumulative effects of sowing rate, sowing date and cultivar choice on weed competition. Crop Protection. 2017. № 95. P. 109-115. DOI 10.1016/j.cropro.2016.05.00

12. Swanston, J.S. Newton, A.C., Brosnan, J.M., Broadhead, A., Glasgow, E. Determining the Spirit Yield of Wheat Varieties and Variety Mixtures. Journal of Cereal Science. 2005. № 42. P. 127-134.

13. Guzhov, Yu.L., Komar, O.A. Competitiveness of plants of wheat varieties having different stem lengths when sowing in a mixture and separately. VASKhNIL Reports. 1981. 1, № 6 (rus)

14. Chekalin, N.M., Yakovlev, V.L., Varlakhov, M.D. Report II. The effect of genotypic and environmental competition on the quantitative traits of peas, Genetics. 1983. 19, № (8). P. 1308-1311 (rus)

15. Donald, C.M. The breeding of crop ideotypes. Euphytica. 1968. № 17(3), P. 385-403.

16. Fasoulas, A. Correlation between auto-, allo- and nilcompetition and their implication in plant Breeding. Euphytica. 1990. № 50(1). P. 57-62.

17. Hamblin, J., Rowell, J.G. Breeding implication of the relationship between competitive ability and pure culture yield in self-pollinated grain crops. Euphytica. 1975. № 24(1). P. 221-228.

18. Gedge, D.L. et al. Influence of intergenotypic competition on seed yield of geterogeneous soybean lines. Crop Sci. 1978. № 18(2). 233 P.

19. Nikitenko, G.F., Gorkov, V.P. Features of the selection of elite plants on continuous ordinary crops. Selection and seed production. 1976. № 2. P. 66-68. (rus)

20. Chekalin, N.M., Yakovlev, V.L., Varlakhov, M.D. Genotypic and environmental competition in peas (Pisum sativum L.). Report I. The effect of genotypic competition on seed productivity in peas. Genetics. 1983. № 19(8). P. 1301-1307. (rus)

21. Dragavtsev, V.A. New principles for the selection of genotypes by quantitative traits in plant breeding. Genetics of quantitative traits of agricultural plants. Moscow: Science. 1978. P. 5-9. (rus) 
22. Dyakov, A.B., Dragavtsev, V.A. Competitiveness of plants according to the breeding. Report 1 . Reliability of the assessment of genotypes by phenotypes and the way to increase it. Genetics. 1975. № 11(5). P. 11-22. (rus)

23. Dolotovsky, I.M Genetic and breeding aspects of the mutual influence of plants. Ufa : BFAN USSR. 1987. 102 p. (rus)

24. Smalko, A.A. Mathematical analysis of the relationship between the productivity of plants and their populations. Genetics of quantitative traits of agricultural plants, Moscow : Science. 1978. P. 34-47. (rus)

25. Chekalin. N.M., Belyaeva, E.G. Variability of characters in winter wheat populations depending on the type and direction of selection. Breeding and Seed Production. 1986. № 2. P. 15-16. (rus)

26. Dragavtsev. V.A., Shkel, N.M. Problems of increasing the efficiency of selection in plants. Biol. fundamentals of breeding for productivity, Tallinn. 1981. P. 102-105. (rus)

27. Konovalov, Yu.B., Al-Sobakhi, S.S. Forecast of the effectiveness of selection from crops of various densities in varieties of spring soft wheat. TSHA Reports. 1983. № 5. P. 43-50. (rus)

28. Maltsev, A.V., Dragavtsev, V.A., Burdun, A.M. Effects of plant interactions in phytocenoses. St. Petersburg. 1991. 44 p. (rus)

29. Tishchenko, V.N., Chekalin, N.M. Genetic principles of adaptive breeding of winter wheat in the forest-steppe zone. Poltava. 2005. 270 p. (rus)

30. Essah, S.Y.C., Stoskopf, N.C. Mixture performance of phenotypically contrasting barley cultivars. Can. J. Plant Sci. 2001. № 82. P. 1-6.

Information about authors: Tishchenko V. M.,

Doctor of Agricultural Sciences, Professor, Head of Department of Plant Breeding, Seed Growing and Genetics

Poltava State Agrarian Academy 1/3, Skovorody str., Poltava, 36003, Ukraine

Kolesnik A. V.,

Candidate of Biological Sciences, Associate Professor of Department of Plant Breeding, Seed Growing and Genetics

Poltava State Agrarian Academy 1/3, Skovorody str., Poltava, 36003, Ukraine

Batashova M. Ye.,

Candidate of Biological Sciences, Associate Professor of Department of Plant Breeding, Seed Growing and Genetics

Poltava State Agrarian Academy 1/3, Skovorody str., Poltava, 36003, Ukraine 